University of Nebraska - Lincoln

DigitalCommons@University of Nebraska - Lincoln

1984

\title{
Effects of Weather on Habitat Selection and Behavior of Mallards Wintering in Nebraska
}

Dennis Jorde

Gary Krapu

USGS, gkrapu@usgs.gov

Richard Crawford

Miriam Hay

Follow this and additional works at: https://digitalcommons.unl.edu/usgsnpwrc

Part of the Other International and Area Studies Commons

Jorde, Dennis; Krapu, Gary; Crawford, Richard; and Hay, Miriam, "Effects of Weather on Habitat Selection and Behavior of Mallards Wintering in Nebraska" (1984). USGS Northern Prairie Wildlife Research Center. 63.

https://digitalcommons.unl.edu/usgsnpwrc/63

This Article is brought to you for free and open access by the US Geological Survey at DigitalCommons@University of Nebraska - Lincoln. It has been accepted for inclusion in USGS Northern Prairie Wildlife Research Center by an authorized administrator of DigitalCommons@University of Nebraska - Lincoln. 


\title{
EFFECTS OF WEATHER ON HABITAT SELECTION AND BEHAVIOR OF MALLARDS WINTERING IN NEBRASKA
}

\author{
DENNIS G. JORDE \\ GARY L. KRAPU \\ RICHARD D. CRAWFORD \\ AND \\ MIRIAM A. HAY
}

\begin{abstract}
Sex and age ratios, habitat selection, spatial characteristics, and time budgets of Mallards (Anas platyrhynchos) wintering on the Platte River in south central Nebraska were studied from mid-December to early April 19781980. The proportion of females and subadults in the population increased substantially from a cold to a mild winter. Radio-tagged Mallards shifted from riverine to canal roost sites during the coldest periods of the winter, seemingly because of more favorable microclimatic conditions there. Subadults ranged over larger areas during winter than did adults. Activity patterns varied with weather conditions, time of day, and habitat type. During cold periods, energetically costly activities such as aggression and courtship decreased at roost sites and the intensity of foraging activities in fields increased. Mallards were more active at riverine than canal sites during both years. High energy requirements and intense competition for scarce food appear to be primary factors limiting the northernmost distribution of Mallards in winter and causing their skewed sex and age ratios.
\end{abstract}

Severe weather conditions, especially low temperatures, are known to cause stress and affect the distribution and movements of waterfowl during winter (LeFebvre and Raveling 1967, Reed 1971, Cain 1973, Bennett and Bolen 1978, Prince 1979). Some Mallard (Anas platyrhynchos) populations winter farther north than most other waterfowl species (Bellrose 1980). How these birds have adapted to northern environments during winter and the factors that limit their winter distribution in North America are poorly understood and were the subjects of our study.

More specifically, we examined habitat use and behavior of Mallards on a site north of the traditional winter range of the species. Our objectives were to (1) study the effects of weather patterns and microclimate on daily movements and habitat selection of Mallards, and (2) record nocturnal and diurnal behavior of these birds in several habitats during variable climatic conditions.

\section{STUDY AREA AND METHODS}

The study area was located along the Platte River in south central Nebraska (Fig. 1). Data were collected principally in areas near the river from Gibbon to Kearney and Elm Creek to Lexington. These areas contain ice-free channels and canals used by wintering Mallards. Most of the surrounding land is privately owned and used for corn and livestock production. Much of this land is irrigated and several canals traverse parts of it, particularly between Lexington and Elm Creek.

Data were collected from mid-December to mid-March in 1978-1979 and 1979-1980. We observed the ducks' diurnal activities using a $20 \times$ spotting scope and Questar $1300-\mathrm{mm}$ scope. Nocturnal activities were observed with a Javelin Model 226 long-distance night-viewing device equipped with a $300-\mathrm{mm}$ lens.

We recorded the ducks' activities at 12-s intervals with the aid of a metronome timer. Individual Mallards were randomly selected by locating a group of birds in the scope's field of view and, after looking away and slightly moving the instrument horizontally and/or vertically, observing the individual nearest to the point where the cross hairs intersected. Data were collected continuously for $1-60 \mathrm{~min}$ for each individual observed. Nocturnal activities were only recorded during clear or nearly clear nights so that we could determine a duck's sex at distances up to $100 \mathrm{~m}$. Snow on surrounding areas and/or moonlight greatly improved visibility. The male's dark head was the most prominent characteristic at night. Activities identified in this paper are:

Sleeping. Resting, with the head usually held close to the body or lying on the back with bill tucked into the feathers.

Swimming. Aquatic locomotion not directly associated with feeding, but including bathing.

Walking. Terrestrial locomotion not directly associated with feeding. 

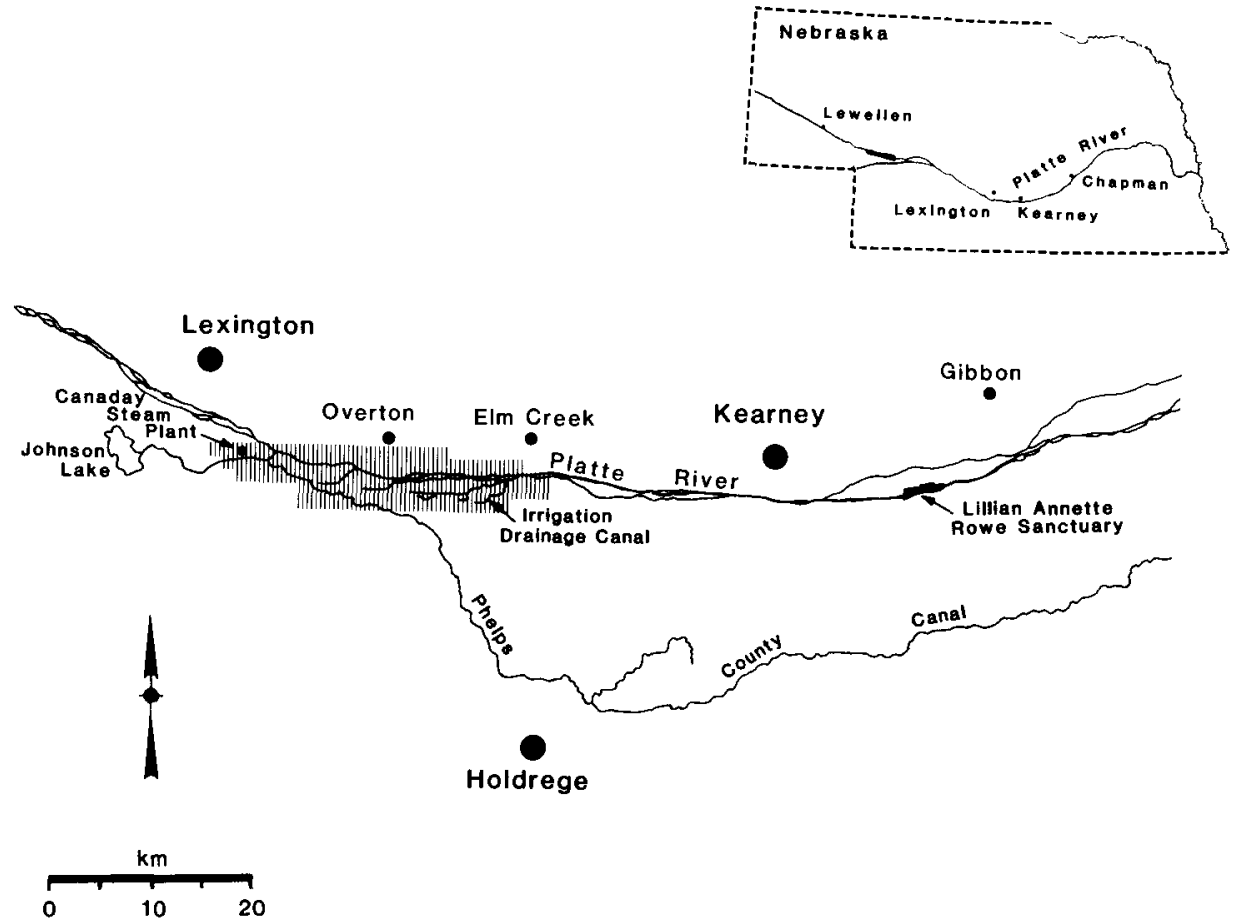

FIGURE 1. The Platte River study area in south central Nebraska. Telemetry area shaded.

Comfort movements. Maintenance activities such as preening and stretching.

Feeding in water. Surface and subsurface feeding from canals or riverine sites.

Feeding in fields. Foraging on grains in fields.

Courtship. Inciting, head-pumping, and other pair-bonding and copulatory behaviors.

Alert. Head up, usually stretched, and cessation of activities.

We captured 19 Mallards with rocket nets, bait traps, or drive traps and fitted them with transmitters similar to those used by Dwyer (1972). Two birds that were monitored for fewer than eight days were excluded from analyses. Radio-tagged birds were followed from 14 January to 15 March 1980 on a 28,700 -ha study area near Overton (Fig. 1). Twenty-two percent of this tract consisted of riverine sites (including present and former channels); $47 \%$ was cornfields ( $70 \%$ grazed by cattle, $20 \%$ idle, $9 \%$ fall-tilled); $14 \%$ was hayland (mostly mowed alfalfa); and 13\% grasslands (mostly grazed pastures). Cattle feedlots accounted for $<1 \%$ of the study area. The diurnal locations of radio-tagged ducks were recorded from before dawn to after dusk at hourly intervals when possible. Time and habitat were noted at each location. Telemetry data were analyzed with a computer program developed by Cedar Creek Bioelectronics Laboratory using the grid square, minimum area method. Minimum square area for this study was 16.2 ha. Roost sites were separated into "activity centers" (areas used on three or more consecutive days) and "exploratory sites" (areas used on fewer than three consecutive days). Exploratory sites farther than $0.4 \mathrm{~km}$ from each other were considered separate. Distance of exploratory movements from the principal activity center (area used for the longest number of consecutive days) of each duck was measured from the center of each area. A "roost area" was determined by plotting on a map the outermost locations where a bird spent all its time except when foraging in fields, connecting the points with straight lines, and measuring the enclosed area with a planimeter.

Data on roost microclimate were recorded at a canal $4 \mathrm{~km}$ ESE of the Overton Interstate 80 exit, and along the north bank of the Platte River on the Lillian Annette Rowe Bird Sanctuary near Gibbon from 16 January to 22 February 1980 . Daily maximum-minimum temperatures, relative humidity, and solar radiation were recorded within $30 \mathrm{~cm}$ of the soil or water surface. Monthly weather summaries containing maximum-minimum temperatures and precipitation for Kearney and the Canaday steam plant were obtained from the U.S. Environmental Data Service (19781980).

We also determined the age composition of the population by using wing feathers from Mallards that were either live-trapped or shot 
TABLE 1. Estimated age and sex ratios of Mallards wintering in south central Nebraska, 1979-1980. Age ratios for 1979 are based on a sample of collected birds and for 1980 are based on live-trapped birds.

\begin{tabular}{|c|c|c|c|c|}
\hline \multirow[b]{2}{*}{ Season } & \multicolumn{3}{|c|}{ Adults/subadults } & \multirow[b]{2}{*}{$\begin{array}{l}\text { Male-to-female } \\
\text { ratio }(n)\end{array}$} \\
\hline & $\underset{(n)}{\text { Males }}$ & $\underset{(n)}{\text { Females }}$ & $\begin{array}{c}\text { Sexes } \\
\text { combined } \\
(n)\end{array}$ & \\
\hline 1979 & $2.6(47)$ & $2.5(21)$ & $2.6(68)$ & $2.78(140)$ \\
\hline 1980 & $1.3(83)$ & $2.0(36)$ & $1.5(119)^{\mathrm{a}}$ & $1.58(15,435)^{b}$ \\
\hline
\end{tabular}

(Krapu et al. 1979), and sex ratios from counts of males and females at roost sites using aerial photography (Ferguson et al. 1981), ground counts, and observations of birds during foraging flights. Mallards wintering on the Platte River between Chapman and Lewellen, $\mathrm{Ne}$ braska, were aerial-censused monthly and biweekly during the winters of 1978-1979 and 1979-1980, respectively.

Habitats on the study area were identified and plotted on 1:24,000 U.S. Geological Survey topographic maps. Field boundaries visible on U.S. Department of Agriculture (USDA) aerial photographs were transferred to topographic maps and verified by ground inspection. Cropland areas planimetered by the USDA were used when existing field boundaries were the same as those shown on the aerial photographs; otherwise, areas were estimated with a dot grid.

Differences in the birds' use of riverine, canal, and other habitats were analyzed with a functional categorical procedure that provides a Chi-square analog of analysis of variance (Grizzle et al. 1969, SAS 1982). The number of times that Mallards were observed in each of these habitats was transformed to a logarithmic value for the analysis. The effects of age and sex on the ducks' movements and the size of their roosting areas were examined with conventional analyses of variance.

\section{RESULTS}

\section{POPULATION CHARACTERISTICS}

The peak density of Mallards increased fivefold from the cold winter of 1979 to the mild
TABLE 2. Mean daily temperature and relative humidity at riverine and canal roost sites occupied by wintering Mallards during 1980.

\begin{tabular}{|c|c|c|c|c|}
\hline \multirow[b]{2}{*}{ Location } & \multicolumn{2}{|c|}{ Temperature $\left({ }^{\circ} \mathrm{C}\right)$} & \multicolumn{2}{|c|}{ Relative humidity (\%) } \\
\hline & Maximum & Minimum & Maximum & Minimum \\
\hline \multicolumn{5}{|l|}{ Roost sites $^{\mathrm{a}}$} \\
\hline Riverine & 9.4 & -9.4 & 67.1 & 50.4 \\
\hline Canal & 5.6 & -7.2 & 85.9 & 65.3 \\
\hline \multicolumn{5}{|l|}{ U.S. weather stations } \\
\hline $\begin{array}{l}\text { Kearney Airport } \\
\text { Canaday Steam }\end{array}$ & -0.6 & -11.1 & - & - \\
\hline Plant & 0.0 & -11.1 & - & - \\
\hline
\end{tabular}

winter of 1980 (5,000 vs. 25,000 birds). With colder temperatures and more severe weather conditions, Mallard populations decreased 39 and $75 \%$ by mid-February 1979 and 1980 , respectively. Adults made up $72 \%$ of the population during winter 1979 and $62 \%$ during 1980 (Table 1). During 1979, 74\% of the population consisted of males, compared with 52$61 \%$ for winter 1980 (Ferguson et al. 1981).

\section{CHARACTERISTICS OF ROOST SITES}

Riverine areas and drainage canals that were used as roost sites by wintering Mallards had similar characteristics. Riverine roosts were ice-free flood pools and beaver (Castor canadensis) impoundements adjacent to treeless sandbars and close to wooded banks and islands. Most of these sites faced the sun and were sheltered from the prevailing northwest wind by high banks and woods. East-west canals with high north banks were also often used as roosts, especially if they had trees on the north bank that afforded protection from northwest winds and prevented snow from drifting into the canal. The width of the canal at these roost sites was $13.5 \pm 1.8 \mathrm{~m}(\bar{x} \pm \mathrm{SD})$ at bank apex and $7.4 \pm 1.6 \mathrm{~m}$ at water level. The bank's height was $2.1 \pm 0.4 \mathrm{~m}$ above the water's surface on the north side and $1.1 \pm$ $0.2 \mathrm{~m}$ on the south side. The lower height of the south bank allowed more sunlight to strike the north bank, which increased the ambient temperatures of these sites and ameliorated the

TABLE 3. Habitats used by 17 radio-tagged Mallards along the Platte River in south central Nebraska during winter 1980.

\begin{tabular}{|c|c|c|c|c|c|c|c|c|}
\hline & \multirow[b]{2}{*}{$n$} & \multirow[b]{2}{*}{$\begin{array}{l}\text { Mean body } \\
\text { weight }(g)\end{array}$} & \multirow{2}{*}{$\begin{array}{l}\text { Number of } \\
\text { locations } \\
\text { recorded }\end{array}$} & \multicolumn{5}{|c|}{ Habitat use ( $\%$ of locations recorded) } \\
\hline & & & & Riverine & Canal & $\begin{array}{c}\text { Grazed corn } \\
\text { stubble }\end{array}$ & $\begin{array}{c}\text { Cultivated } \\
\text { stubble }\end{array}$ & $\begin{array}{l}\text { Other } \\
\text { areas }\end{array}$ \\
\hline Adult males & 5 & 1,266 & 1,019 & 38.5 & 52.9 & 5.3 & 0.2 & 3.1 \\
\hline Subadult males & 3 & 1,230 & 528 & 55.7 & 38.4 & 3.6 & 0.2 & 2.1 \\
\hline Adult females & 5 & 1,140 & 984 & 44.3 & 49.3 & 2.7 & 0.1 & 3.6 \\
\hline Subadult females & 4 & 1,023 & 528 & 61.0 & 36.6 & 1.1 & 0.0 & 1.3 \\
\hline All birds & 17 & & 3,059 & 47.2 & 46.4 & 3.5 & 0.1 & 2.8 \\
\hline
\end{tabular}




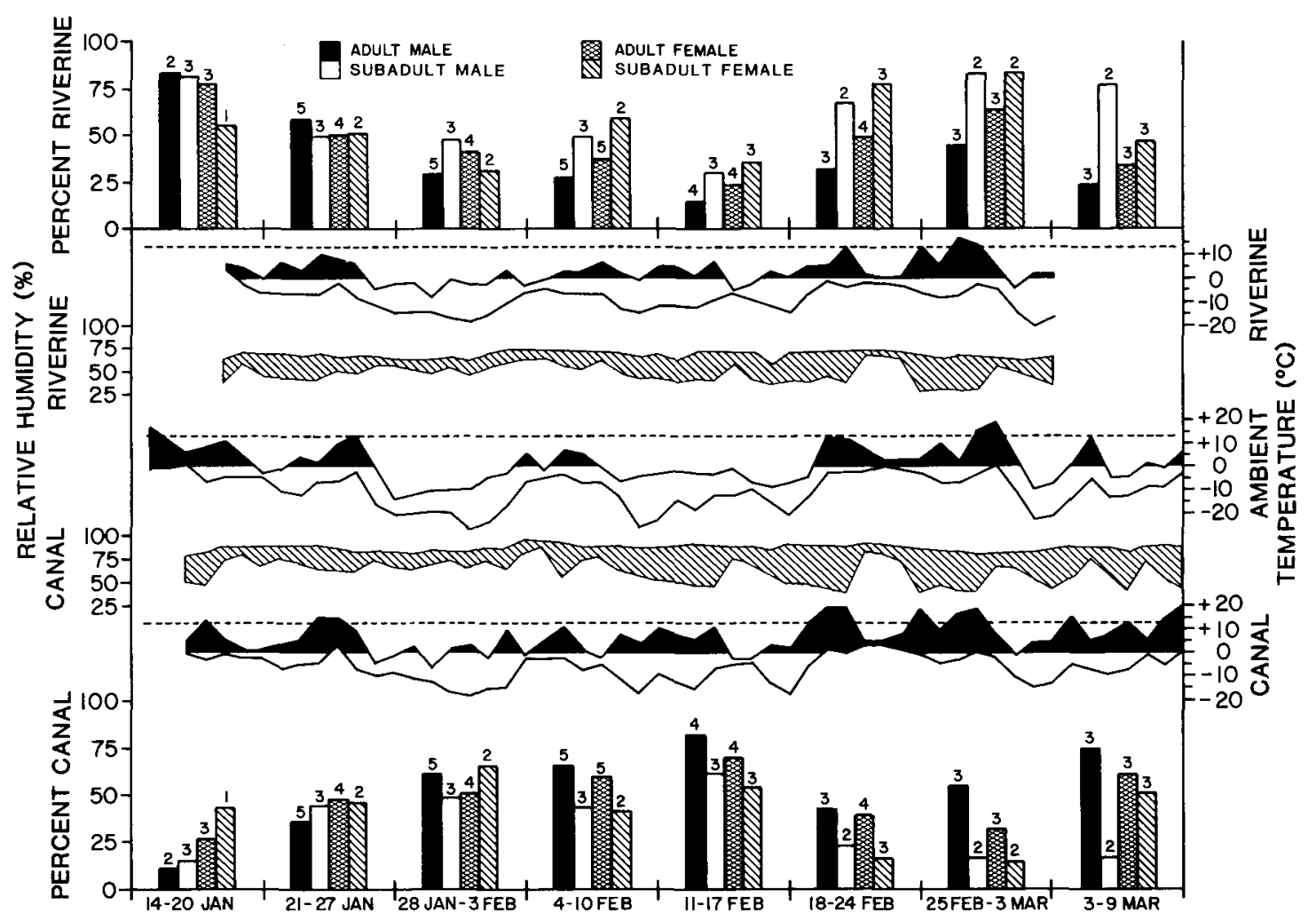

FIGURE 2. Influence of temperature and relative humidity on habitat use by radio-tagged Mallards during winter 1980. Dashed line represents the estimated lower critical temperature $\left(T_{\mathrm{lc}}\right)$ of the ducks. Temperature and relative humidity are daily maxima and minima. Temperatures above $0^{\circ} \mathrm{C}$ are shaded. Histobars represent the $\%$ of each sex and age class at riverine and canal locations during each period. Sample sizes (number of ducks) are above the histobars.

effects of prevailing winds on their microclimate. Maximum water depth was $23.7 \pm 5.5$ $\mathrm{cm}$.

The temperatures at the ducks' roost sites were different from one another and from those reported at nearby weather stations (Table 2). Riverine temperature was warmer $(-24.4$ to $\left.20.0^{\circ} \mathrm{C}\right)$ than the ambient temperature $(-26.7$ to $12.2^{\circ} \mathrm{C}$ ) at the Kearney U.S. Weather Station nearby. Maximum and minimum temperatures along the river also exceeded ambient temperatures recorded concurrently at Kearney 87 and $61 \%$ of the time, respectively. Air temperatures along the canals were also warmer $\left(-22.0\right.$ to $\left.16.1^{\circ} \mathrm{C}\right)$ than ambient temperatures $\left(-26.7\right.$ to $\left.12.8^{\circ} \mathrm{C}\right)$ at the Canaday U.S. Weather Station nearby. Average daily maximum and minimum temperatures between Kearney and Canaday were similar (Table 2). However, in riverine habitats maximum temperatures were $68 \%$ warmer and minimum temperatures were $31 \%$ colder than corresponding canal temperatures.

Relative humidity was $22 \%$ lower in riverine habitats than in canals. It was highest at night (22:00-08:00) $-67 \pm 4.2 \%$ in riverine habitats and $86 \pm 4.2 \%$ in canals - and lowest during the day (08:00:22:00) $-50 \pm 9.0 \%$ in riverine habitats and $65 \pm 12.8 \%$ along the canals.

\section{HABITAT USE}

Radio-tagged wintering Mallards roosted in riverine areas and irrigation drainage canals 47 and $46 \%$ of the time, respectively (Table 3 ). They preferred areas of open water sheltered by trees and high banks, and having slightly elevated sandbars and vegetated areas. Adult males and females roosted in drainage canals 53 and $49 \%$ of the time, respectively, whereas subadult males and females occupied riverine habitats 56 and $61 \%$ of the time. Observed differences in habitat-use patterns between the sexes were statistically significant $\left(x^{2}=35.1, P<0.001\right)$ whereas age-related differences were not $\left(x^{2}=0.02, P>0.10\right)$.

Movements between canal and riverine habitat were associated with changes in ambient temperature, the temperature and relative humidity at the roost site, and ice formation (Fig. 2). During the coldest periods (28 January-3 February, 11-17 February, 3-9 March), Mallards congregated in the canals, which were warmer than elsewhere, but they returned to riverine areas when ambient temperature rose. Although maximum and minimum relative humidity were lower and more stable in riverine areas, these areas were also more exposed to windchill, resulting in rapid ice formation. 
TABLE 4. Spatial characteristics of habitat used by 14 radio-tagged Mallards wintering in south central Nebraska during 1980.

\begin{tabular}{cccc}
\hline \hline Bird number & $\begin{array}{c}\text { Number of } \\
\text { observations }\end{array}$ & $\begin{array}{c}\text { Roost area } \\
\text { (ha) }\end{array}$ & $\begin{array}{c}\text { Number of } \\
\text { activity } \\
\text { centers }\end{array}$ \\
\hline Adult male & & & \\
3 & 125 & 2,106 & 2 \\
4 & 156 & 3,340 & 4 \\
10 & 217 & 3,608 & 2 \\
12 & 279 & 3,490 & 2 \\
13 & 167 & 3,235 & 2 \\
Mean & - & 3,156 & 2.4 \\
Adult female & & & \\
2 & 304 & 2,997 & 4 \\
7 & 108 & 2,409 & 2 \\
11 & 235 & 2,594 & 3 \\
14 & 231 & 2,685 & 3 \\
Mean & - & 2,671 & 3.0 \\
Subadult male & & & \\
5 & 221 & 4,524 & 5 \\
6 & 124 & 3,694 & 4 \\
8 & 146 & 3,879 & 4 \\
Mean & - & 4,032 & 4.3 \\
Subadult female & & & \\
1 & 272 & 3,458 & 2 \\
19 & 114 & 3,393 & 4 \\
Mean & - & 3,425 & 3.0 \\
\hline Activity center $=$ an area used on three or more consecutive days.
\end{tabular}

During the severe 1979 winter, extensive ice forced Mallards to leave most river areas. During the period shown in Figure 2, however, ice formation was not extensive or prolonged, suggesting that other variables (e.g., intraspecific competition) caused the ducks to shift between habitats.

When not at roost sites, Mallards were usually grazing in cropland, especially corn stubble fields (Table 3 ). Cultivated and plowed corn stubble fields were used most often after snowstorms because strong winds prevented or reduced the accumulation of snow there. Cattle feedlots also attracted large number of birds, especially after snowstorms and when snow was deep. Mallards occasionally used mowed alfalfa fields, grazed pastures, and marshes that contained shallow pools suitable for dabbling and loafing during the day.

Roost areas of radio-tagged subadults averaged $28 \%$ larger than those of adults (Table $4, F=12.53, P<0.005)$. This difference was associated with the younger birds' tendency to be more mobile and occupy more activity centers (Table $4, F=4.21, P<0.065$ ). The number of exploratory sites used did not vary significantly by age $(F=1.95, P>0.10)$ or sex $(F=1.80, P>0.10)$, nor did the distance of exploratory flights vary significantly by age $(F=$
$1.37, P>0.10)$ or $\operatorname{sex}(F=1.40 P>0.10)$. Males occupied larger roosting areas than did females (Table 4, $F=5.15, P<0.05$ ).

\section{ACTIVITY PATTERNS}

During winter 1979, Mallards foraged more intensively in agricultural habitats and spent less time searching for aquatic food than during winter 1980 (Table 5). They also slept less and were less aggressive and alert during 1979. Courtship activity was lower during the day in 1980 than in 1979.

Comfort movements, aquatic feeding, and sleeping were the major activities at dawn (Table 5). Birds slept most at mid-morning (09: 00-10:59) during both winters, and spent much time sleeping throughout the day, except during the evening foraging period (17:00-19:00). Sleeping tapered off after mid-morning during 1979 , but peaked again in the early afternoon (13:00-14:59) during 1980. Swimming, mainly associated with aquatic feeding, courtship, and comfort movements (including bathing), accounted for $4-15 \%$ of the ducks' daily time budget. The number of birds feeding and walking in fields increased slowly from mid-morning to late afternoon. Mallards were also more alert during the afternoon than in the morning. We saw courtship and aggressive behavior throughout the day, but it was only a small part of the birds' daily time budgets. During winter 1980, Mallards were very active at night (19:00-07:00), swimming, feeding on the water, and performing comfort behaviors 19,29 , and $64 \%$ more, and sleeping $17 \%$ less than during the day. Aggression and courtship increased 100 and $275 \%$ at night.

Mallards were more active in riverine habitats than in canals (Fig. 3). Aquatic feeding was $45 \%$ higher in these habitats during winter 1979 and the ducks spent more time swimming there during $1979(21 \%)$ than in 1980 (11\%). No such differences in swimming activity occurred in the canals during the two winters (12 vs. 13\%). Comfort activity was greater at canal roosts during 1979 and greater at riverine roosts during 1980. Courtship was higher in riverine habitats than in canals during both winters.

\section{DISCUSSION}

The sex and age composition in wintering flocks of Mallards in Nebraska and use of the sites as a wintering ground by individual birds varied with weather conditions. Bellrose and Crompton (1970) suggested that subadult Mallards established wintering sites to which they then returned as adults. However, Albright (1981) thought that when early winter was un- 
TABLE 5. Activity patterns (\% of time budget observations) of Mallards during severe (1979) and mild (1980) winters in south central Nebraska. Diurnal activities have been subdivided into 2 -h periods plus a 12 -h summary. Nocturnal observations (from 1980 only) are combined into one 12-h period. The 1979 percentages are listed first during each time period.

\begin{tabular}{|c|c|c|c|c|c|c|c|c|}
\hline \multirow[b]{3}{*}{ Activity } & \multicolumn{8}{|c|}{ Time period } \\
\hline & \multicolumn{7}{|c|}{ Diurnal" } & \multirow{2}{*}{$\begin{array}{c}\text { Noc- } \\
\text { turnal } \\
19: 00 \\
07: 00\end{array}$} \\
\hline & 07:00-08:59 & $09: 00-10: 59$ & $11: 00-12: 59$ & $13: 00-14: 59$ & $15: 00-16: 59$ & $17: 00-19: 00$ & $07: 00-19: 00$ & \\
\hline Courtship & $1.5 / 0.0$ & $1.1 / 0.1$ & $1.0 / 0.3$ & $1.8 / 0.7$ & $0.0 / 0.7$ & $0.1 / 0.0$ & $1.0 / 0.4$ & 1.0 \\
\hline Alert & $3.6 / 5.3$ & $1.4 / 1.2$ & $2.7 / 5.7$ & $2.2 / 6.6$ & $9.6 / 10.8$ & $14.8 / 8.0$ & $4.9 / 6.9$ & 5.5 \\
\hline Feeding in fields & $0.0 / 0.0$ & $1.6 / 0.0$ & $2.4 / 2.8$ & $14.9 / 0.6$ & $31.8 / 16.8$ & $51.8 / 44.6$ & $15.8 / 8.1$ & 0.0 \\
\hline Feeding in water & $12.7 / 30.5$ & $10.5 / 17.1$ & $12.5 / 35.8$ & 16.5 & 9.3 & $0.0 / 21.8$ & $11.2 / 23.6$ & 20.3 \\
\hline Comfort movements & $38.9 / 27.6$ & $18.8 / 18.2$ & $28.2 / 12.3$ & $23.9 / 13.5$ & $18.3 / 13.7$ & $13.9 / 2.8$ & $22.0 / 14.1$ & 22.1 \\
\hline Walking & $4.5 / 2.4$ & $1.5 / 3.0$ & $3.1 / 2.1$ & $4.3 / 4.2$ & $15.0 / 6.3$ & $16.8 / 17.8$ & $7.0 / 5.0$ & 0.3 \\
\hline Swimming & $10.6 / 11.3$ & $14.7 / 0.0$ & $9.8 / 9.8$ & $8.6 / 8.4$ & $4.1 / 13.1$ & $0.0 / 1.7$ & $8.6 / 8.6$ & 8.8 \\
\hline Sleeping & $28.2 / 19.9$ & $50.4 / 59.5$ & $40.3 / 29.3$ & $27.6 / 45.4$ & $11.3 / 16.1$ & $2.1 / 0.0$ & $29.4 / 31.4$ & 39.2 \\
\hline
\end{tabular}

- Sample size $=54.0 \mathrm{~h}(1979)$ and $47.1 \mathrm{~h}(1980)$.

- Sample size $=11.9 \mathrm{~h}(1980)$.

usually cold, migrating American Black Ducks (A. rubripes) continued southward rather than settling in more northerly wintering sites, and that the severity of the previous winter(s) influenced number, sex, and age of subsequent local winter populations. If cold temperatures and snow cover are present in Nebraska during late fall migration, subadults may pass through the State, whereas under milder weather conditions they overwinter there with winter resident adults. Our data show that more subadults, especially males, stayed to winter on the Platte River in 1979-1980 when temperatures were warmer than during 1978-1979, when temperatures were colder and, therefore, support the hypotheses of both Albright, and of Bellrose and Crompton.

Intense competition and high expenditure of energy during periods of colder weather and snow cover are probably dominant factors governing the distribution of Mallards in winter and their fidelity to wintering grounds. Adult male Common Mergansers (Mergus merganser) form a higher proportion of the wintering population at northern latitudes than do females and immatures, probably because their larger body size permits them to adapt better to colder climatic conditions (Anderson and Timken 1972). Nichols and Haramis (1980) and Saylor and Afton (1981) suggested that, because of their subdominance, female Canvasbacks (Aythya valisineria) and Common Goldeneyes (Bucephala clangula) were excluded from the best foraging sites and thereby restricted in their wintering distribution. Unmated males and paired birds were most dominant in wintering flocks in Nebraska. In addition, inexperienced and subordinate subadults often must compete intensively with adults for limited space and food on northern wintering grounds and so are likely the first birds that emigrate at the onset of severe weather. Our censuses indicated that birds which left the Platte River during mid-winter did not return when severe conditions abated; therefore, we do not know which wintering area became traditional for them. Perhaps the mid-winter movement of Mallards, banded in northern areas during early winter, to southern wintering grounds, where they could mix with other populations, partly explains movement of Mallards between flyways based on band returns (e.g., Hopper et al. 1978, Hyland and Gabig 1979). However, once the birds establish a traditional wintering ground, fidelity to that site by adults is strong (Sugden et al. 1974, Limpert 1980, Nichols and Haramis 1980).

The movements of Mallards between riverine and canal habitats in Nebraska are associated with variations in microclimate, the energetic costs of thermoregulation, and intraspecific behavior. Wintering waterfowl generally lose weight and are in their poorest physical condition during periods of cold stress (Reinecke 1977, Prince 1979, Paulus 1980, Jorde 1981). Therefore, their movements may be a behavioral response to lessen the effects of harsh weather whereby they select microclimates that require lower energy expenditures for thermoregulation, as has been shown for other avian species (Krantz and Gauthreaux 1975, Lustick et al. 1978, DeJong 1979). The lower critical temperature $\left(T_{\mathrm{lc}}\right)$ is $8-14^{\circ} \mathrm{C}$ for Black Ducks (Wooley and Owen 1977) and $18-25^{\circ} \mathrm{C}$ for fasted Mallards (Prince 1979). That of winter-acclimated Mallards in the wild is probably similar to the $T_{\mathrm{lc}}$ of Black Ducks because the two species are similar in size and weight. During the cold periods shown in Figure 2, canal temperature more closely ap- 


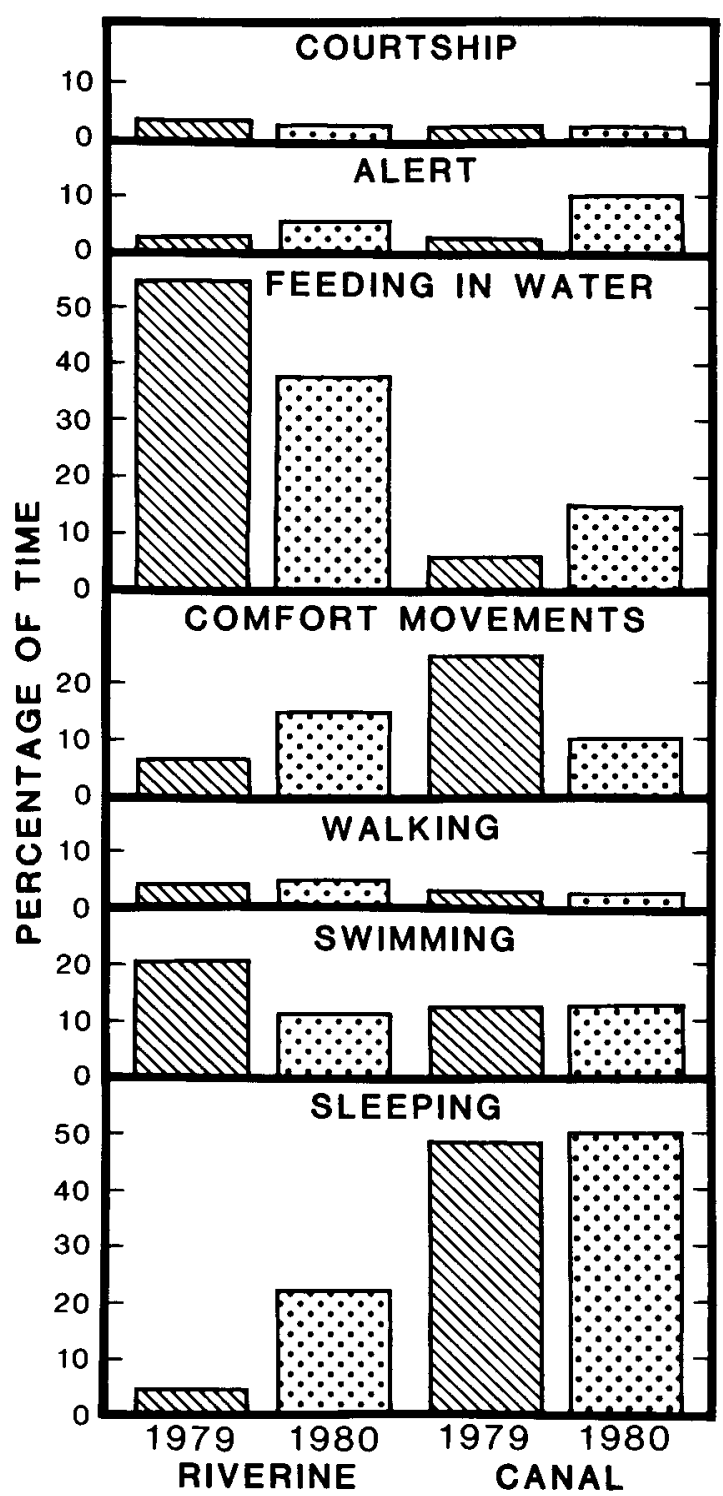

FIGURE 3. Diurnal activity patterns of male (diagonal lines) and female (dots) Mallards at riverine and canal roost sites during severe (1979) and mild (1980) winters in south central Nebraska.

proached the Mallard's $T_{\mathrm{lc}}$ (dashed line) than riverine and ambient temperatures. Therefore, on the basis of the energy required for thermoregulation, canals would probably be the preferred habitats.

During cold periods when canals were the most climatically suitable roost sites for Mallards, the limited water surface and crowding there favored heavier dominant birds, mostly males. However in extreme cold, dominant birds reduced energy-demanding activities, particularly aggression. Paired birds dominated canals and displaced unpaired females to riverine habitats, which may explain why unpaired males congregated at riverine areas where unmated females were most likely to be found. In addition, the scarcity of aquatic foods in the canals (Jorde et al. 1983) reduced foraging success and limited the time that ducks, particularly females, could stay in this habitat. During warm periods, riverine habitats were more suitable areas than canals because aquatic food was more abundant, foraging success was higher, and there was less competition.

Based on a limited sample of radio-tagged birds, subadults seemed to range over a larger area than adults during winter. Their low dominance, inexperience in selecting suitable habitats in which to overwinter, and their unpaired status may have caused them to make more and longer exploratory flights. In general, females moved less than males. Possibly (1) they were less able to maintain body weight (energy reserves) and therefore remained relatively sedentary because flight is energetically costly, (2) they were paired, thereby enabling them to successfully defend good roost sites, and (3) males had to explore more to find unpaired females.

Waterfowl adjust their activity patterns to conserve energy during severe winters and periods of cold (Prince 1979, Hickey 1980, Albright 1981). Courtship activity, for example, decreased during prolonged periods of cold, but resumed when warm ambient temperatures reduced the energy needed for thermoregulation and when Mallards returned to riverine habitats. During severe winters, courtship activity was low and probably limited to daylight hours, i.e., to times of day when ambient temperature was highest and energy required for maintenance was low.

Mallards foraged intensively in cornfields to consume energy-rich corn. However, they also fed in aquatic areas, even during cold periods, probably because these areas contained midge larvae, snails, and other invertebrate foods (Jorde et al. 1983) that are rich sources of calcium and certain other nutrients (Krapu and Swanson 1975) deficient in a diet of corn. In light of this, the difference in feeding activity between the winters of 1979 and 1980 suggests that Mallards may forego a nutritionally balanced diet in order to conserve energy for thermoregulation, especially during long periods of cold weather. Nutrients in native foods eventually must be acquired, but the energy content of animal and plant foods available in aquatic habitats during cold weather may not equal the energy that ducks expend searching for these foods. Mallards were probably better able to maintain a nutritional balance in 1980 than in 1979 because they did not need to spend as much time in thermally favorable, but nutritionally unfavorable canal habitats. 


\section{ACKNOWLEDGMENTS}

We thank J. Cochnar, D. Janke, and G. Lingle for field assistance and T. Frank, D. Johnson, and D. Sparling for help in data analysis. We are grateful to J. Longcore and $\mathrm{K}$. Reinecke for reviewing an earlier draft of this manuscript.

\section{LITERATURE CITED}

Albright, J. J. 1981. Behavioral and physiological responses of coastal wintering Black Ducks (Anas rubripes) to changing weather in Maine. M.Sc. thesis, Univ. of Maine, Orono.

Anderson, B. W., And R. L. Timken. 1972. Sex and age ratios and weights of Common Mergansers. J. Wildl. Manage. 36:1127-1133.

Bellrose, F. C. 1980. Ducks, geese and swans of North America. Stackpole Books, Harrisburg, PA.

Bellrose, F. C., AND R. D. Crompton. 1970. Migrational behavior of Mallards and Black Ducks as determined from banding. Ill. Nat. Hist. Surv. Bull. 30 167-234.

Bennetr, J. W., And E. G. Bolen. 1978. Stress response in wintering Green-winged Teal. J. Wild. Manage. 43: $81-86$.

CAIN, B. W. 1973. Effect of temperature on energy requirements and northward distribution of the Blackbellied Tree Duck. Wilson Bull. 85:308-317.

DEJong, A. A. 1979. Thermal irradiation preferences of White-crowned Sparrows in relation to ambient temperature. Physiol. Behav. 22:157-171.

Dwyer, T. J. 1972. An adjustable radio-package for ducks. Bird-Banding 43:282-284.

Ferguson, E. L., D. G. Jorde, and J. L. Sease. 1981. Use of 35-mm color aerial photography to acquire Mallard sex ratio data. Photogramm. Eng. Remote Sensing 47:823-827.

Grizzle, J. E., C. F. Staimer, and G. G. Koch. 1969. Analysis of categorical data by linear models. Biometrics 25:489-504.

HICKEY, T. E., JR. 1980. Activity budgets and movements of Black Ducks (Anas rubripes) in Prince Edward Island. M.Sc. thesis, McGill Univ., Montreal, Quebec.

Hopper, R. M., H. D. Funk, AND D. R. ANDERSON. 1978. Age specificity in Mallards banded postseason in eastern Colorado. J. Wildl. Manage. 42:263-270.

Hyland, J. M., AND P. J. Gabig. 1979. Survival and recovery distribution of central and western Mississippi flyway winter-banded Mallards. Nebraska Game and Parks Comm., Lincoln.

JORDE, D. G. 1981. Winter and spring staging ecology of Mallards in south central Nebraska. M.Sc. thesis, Univ. of North Dakota, Grand Forks.

Jorde, D. G., G. L. Krapu, AND R. D. Crawford. 1983. Feeding ecology of Mallards wintering in Nebraska. J. Wildl. Manage. 47:1044-1053.

Krantz, P. E., and S. A. Gauthreaux, JR. 1975. Solar radiation, light intensity, and roosting behavior in birds. Wilson Bull. 87:91-95.

Krapu, G. L., D. H. Johnson, And C. W. Dane. 1979. Age determination of Mallards. J. Wildl. Manage. 43: 384-393.

Krapu, G. L., and G. A. Swanson. 1975. Some nutritional aspects of reproduction in prairie nesting Pintails. J. Wildl. Manage. 39:156-162.

LeFebvre, E. A., and D. G. Raveling. 1967. Distribution of Canada Geese in winter as related to heat loss at varying environmental temperatures. J. Wildl. Manage. 31:538-546.

LiMPERT, R. J. 1980. Homing success of adult Buffleheads to a Maryland wintering site. J. Wildl. Manage. 44:905-908

Lustick, S., B. Battersby, ANd M. Kelty. 1978. Behavioral thermoregulation: orientation toward the sun in Herring Gulls. Science 200:81-83.

Nichols, J. D., and G. M. Haramis. 1980. Sex-specific differences in winter distribution patterns of Canvasbacks. Condor 82:406-416.

Paulus, S. L. 1980. The winter ecology of the Gadwall in Louisiana. M.Sc. thesis, Univ. of North Dakota, Grand Forks.

PrINCE, H. H. 1979. Bioenergetics of postbreeding dabbling ducks, p. 103-117. In T. A. Bookhout [ed.], Waterfowl and wetlands - an integrated review. North Central Sect. Wildl. Soc.

ReED, L. W. 1971. Use of western Lake Erie by migratory and wintering waterfowl. M.Sc. thesis, Michigan State Univ., East Lansing.

REINECKE, K. J. 1977. The importance of freshwater invertebrates and female energy reserves for Black Ducks breeding in Maine. Ph.D. diss., Univ. of Maine, Orono.

SAS. 1982. SAS user's guide: statistics. SAS Institute, Cary, NC.

SAYloR, R. D., AND A. D. Afton. 1981. Ecological aspects of Common Goldeneyes Bucephala clangula wintering on the upper Mississippi River. Ornis Scand. 12:99-108.

Sugden, L. G., W. J. Thurlow, R. D. Harris, and K. VERMEER. 1974. Investigations of Mallards overwintering at Calgary, Alberta. Can. Field-Nat. 88:303311.

WoOley, J. B., JR., AND R. B. Owen, JR. 1977. Metabolic rates and heart rate-metabolism relationships in the Black Duck (Anas rubripes). Comp. Biochem. Physiol. 57:363-367.

U.S. Fish and Wildlife Service, Northern Prairie Wildlife Research Center, Jamestown, North Dakota 58401. Address of third author: Department of Biology, University of North Dakota, Grand Forks, North Dakota 58202. Present address of first author: College of Forest Resources, 240 Nutting Hall, University of Maine, Orono, Maine 04469. Present address of fourth author: Route 1, Box 302B, Buffalo, Minnesota 55313. Received 23 May 1983. Final acceptance 20 January 1984. 